\title{
BUILDING A CULTURE OF CONSERVATION: RESEARCH FINDINGS AND RESEARCH PRIORITIES ON CONNECTING PEOPLE TO NATURE IN PARKS
}

\author{
Pamela A. Wright ${ }^{*}$ and Carling Matthews ${ }^{2}$ \\ *Corresponding author: pwright@unbc.ca \\ ${ }^{1}$ University of Northern British Columbia, Canada \\ ${ }^{2}$ Jasper National Park, Alberta, Canada
}

\begin{abstract}
Beyond the myriad ecological, economic and cultural values they provide, parks provide a touchstone to the natural world and in an increasingly urbanized and hectic society they are important spaces for building social capital and for building a culture of conservation among citizens. Many park agencies are focusing a great deal of attention on attracting more visitors to parks and offering a broader range of visitor opportunities in parks as ways of building support for parks and protected areas in the future. However, there is little empirical evidence to guide park managers and policy makers on what kinds of activities/ experiences will best connect people to nature in a way that will increase support for conservation. We conducted a review of the literature to identify what is known about the linkage between visitor experiences in parks and public support for conservation; identifying research gaps; and outlining a research agenda in order to build more robust evidence to guide park management. Five main themes and research needs were identified: barriers to park visitation, attitudes towards parks, sense of place, nature connectedness and meaningful nature experiences.
\end{abstract}

Key words: protected areas, visitation, sense of place, nature connectedness, management

\section{INTRODUCTION}

Parks and protected areas are reservoirs of biodiversity, provide critical refugia for species, allow for the provision of ecosystem services, provide carbon-storage to buffer the effects of climate change and offer myriad other ecological benefits. But parks and protected areas also support economic, social and cultural values - including providing nature-based recreation, tourism and education opportunities. In an increasingly urbanized environment, parks provide a touchstone to the natural world; they are important spaces for developing social capital and for building a culture of conservation among citizens.

Growing concern about our disconnect with nature

There is growing recognition of the individual and societal benefits to health and well-being from contact with nature and parks (Lopoukhine et al., 2014; Maller et al., 2008; Weiler et al., 2013; Zylstra, 2014), and concern about the growing disconnect between children (and adults) and the natural environment (Louv, 2008) ${ }^{1}$.
Simultaneously, there is mounting scientific evidence that the ecological health of the planet is declining (IPCC, 2014) including the ecological integrity of parks and protected areas (Canadian Parks and Wilderness Society (CPAWS), 2013; OAGBC, 2010; Office of the Auditor General of Canada, 2013; Parks Canada Agency, 2011). As a result, connecting people to nature and building political support for parks and conservation issues have become priorities for park and conservation organizations.

Fear that disconnect will lead to a decline in support and visits to parks and protected areas In numerous polls and nationwide surveys parks have, and continue to have, a valued place in the minds of Canadians and Americans (Environics Institute, 2009; Hart Research Associates \& North Star Opinion Research, 2012; Ipsos Reid, 2011). However, there is widespread concern that if the populace becomes disconnected from the natural environment, there will be a parallel decline in support for parks and protected areas and other conservation initiatives. 


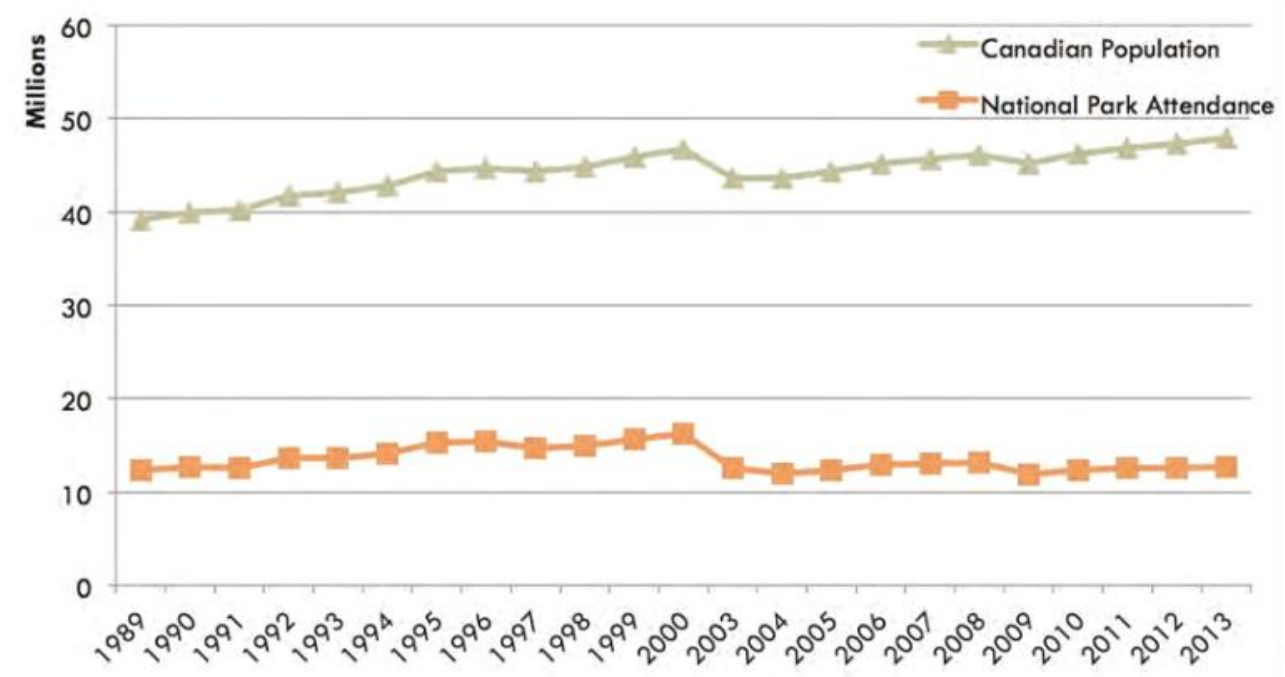

Figure 1. Visitation to Canadian National Parks 1989 to 2013. Note: Data for 2001 and 2002 was unavailable.

Source: Parks Canada Attendance 2008-2009 to 2012-2013; http://www.pc.gc.ca/eng/docs/pc/attend/table1.aspx?m=1

Within North America, visits to parks increased relatively steadily from their establishment through the 1980 s with only minor variations linked to disruptive historical events such as World War II, economic depressions and recessions (Pergams \& Zaradic, 2008). However, between the late 1980 s and late 2000 s, per capita visits to US and Canadian national parks declined. This decline in per capita parks visits has been relatively widespread across Canada and the US and there is some evidence, although not clear, that the trend reflects a broader decline in involvement in nature-based recreation (Balmford et al., 2009; Pergams \& Zaradic, 2008). For provincial parks in Canada and state parks in the US, the trends are fairly similar (Shultis \& More, 2011). Although day trips to some provincial parks have increased, overall visits to provincial parks in Canada have generally declined or are increasing below the rate of population growth.

Although there has been much hand wringing about these declines with fears that they are evidence of the nature disconnect, closer analysis of the data suggests parallels in the periods of decline coincident with economic recessions and social instability (e.g., post 911). In the last five years, actual visits to Canadian national parks have increased approximately 7 per cent (Figure 1) (Parks Canada Agency, 2013).

\section{Limited evidence is available to inform the response}

Many park agencies focus a great deal of attention on attracting more visitors to parks and offering a broader range of visitor opportunities in parks as ways of building support and revenues for parks and protected areas in the future ${ }^{2}$. Some of the strategies being implemented include diversifying the visitor experiences offered in parks, better connecting with urban communities, and attracting more diverse cultural groups to visit parks. However, there is very little empirical evidence to guide park managers and policy makers on what kinds of activities/experiences will best connect people to nature in a way that will increase support for pro-environmental behaviour and conservation initiatives over time. This is compounded by what Amend et al. characterize as 'a growing gap between the formal conservation literature of academia...and the so-called "grey literature" of project reports, articles, NGO studies and working groups' (Amend et al., 2014, p. 8).

This state-of-knowledge report was developed to respond to this information gap by reviewing what we know about the linkage between visitor experiences in parks and public support for conservation; by identifying research gaps in the area; and by outlining a research agenda to begin to address these gaps, in order to build more robust evidence to guide park management.

\section{APPROACH}

This state-of-knowledge (SOK) review summarizes an extensive literature about park visitation and nature connectedness, and how they relate to the goal of building a culture of conservation. It is not an exhaustive summary of all literature that is available, but is focused on synthesizing some of the core concepts in order to identify key findings and gaps to help guide further research and evidence-based decision-making.

This project was designed to address the issue within a North American, and specifically Canadian, context with a focus on natural parks and protected areas. Thus 
national and provincial parks, as opposed to urban/city or historic parks are the focus. We were constrained by examining published work, in English. We are also cognizant that our report is framed from a Western and not an indigenous perspective. However, given that our review of literature was international in scope, we hope that some of this information may be useful beyond North America. Internationally, the healthy parks healthy people movement (see for example the foundational work by Maller et al., 2008) and urban parks initiatives (see for example Trzyna, 2014) frame these issues in a much broader context. We are indebted to those who have written some of the more comprehensive reviews of literature or critical papers that are at the core of this topic (e.g., Canadian Parks Council, 2014; Maller et al., 2008, Shultis \& More, 2011; and Tam, 2012).

The findings are organized in five major subsections: 1) barriers to park visitation, 2) attitudes and the park experience, 3) sense of place, 4) nature connectedness, and 5) emotions and meaningful nature experiences. The paper concludes with the identification of a preliminary list of recommendations for further research.

\section{BARRIERS TO PARK VISITATION}

A decision to visit a park is a function of both interest and opportunity. For individuals, barriers (visitation constraints) to visiting parks are interpersonal (e.g., awareness/knowledge of parks, lack of interest in parks/ park based activities, health concerns or limitations, lack of available time, fear); intra personal (e.g., family demands, social group constraints) or structural (e.g., cost, access difficulties, lack of equipment). This has been an area of significant research over the past 30 years.

Park agencies and advocacy groups often cite an increasingly urbanized, wired, aging and diverse population, along with other socio-demographic phenomena (Canadian Parks Council, 2014) as leading factors in declines in park visitation, empirical evidence that tests for these causes are largely lacking and correlational at best. In fact a recent meta-analysis of 22 North American studies of constraints to park visitation (including urban parks) found that time, cost and knowledge were the most significant constraints preventing people from visiting parks, followed by fear, health, location and access to transportation (Zanon et al., 2013). The types of facilities available and level of interest in parks were the lowest ranked constraints. Income and age had a strong influence on these constraints, followed by education, which had a moderate influence. Specifically, those with higher incomes and younger individuals most frequently cited time as a key constraint, while those with lower incomes were more likely to report most other constraints (except facility availability and interest levels) as significant. Older park visitors were more frequently constrained by health and fear. Gender and race, in spite of much discussion to the contrary in public discourse, had relatively limited influence on constraints to park visits.

\section{Those who are highly motivated to visit parks will find a way}

There is relatively little research and empirical evidence on what strategies can be reasonably pursued to minimize constraints to visitation and whether those strategies will be effective. Recent research suggests that those who are highly motivated (Hubbard \& Mannell, 2001; White, 2008) are likely to put more effort into overcoming barriers to pursuing leisure activities, including visiting parks, and that they will be more successful (Crawford et al., 1991; Hubbard \& Mannell, 2001; Scott \& Mowen, 2010). Increased awareness and information about parks and recreation opportunities, alleviation of safety concerns, and provision of transportation options (c.f. the Ontario, Canada, Parkbus programme www.parkbus.ca) are some of the strategies that have been evaluated and demonstrated some success in reducing visitation constraints (Scott \& Mowen, 2010). In urban park contexts, recent research suggests that an individual's orientation towards nature is a stronger determination of park visits than proximity to green space (Lin et al., 2014). Recent research and recommendations by Trzyna and others (e.g., Trzyna, 2014, 2007) have identified challenges unique to urban protected areas and various strategies used throughout the world to help connect people to nature in urban areas.

\section{Lack of interest and facilities are not key constraints}

Although park visitation is often suggested to be declining because people are less interested in parks, evidence suggests that interest is the least important constraint influencing park visitation (Zanon et al., 2013). Similarly, evidence suggests that the number or type of facilities in parks is not a constraint to park visits.

\section{ATTITUDES AND THE PARK EXPERIENCE}

Within the context of park experiences and support for parks, our values, beliefs and attitudes affect all aspects of the dynamic between interest and understanding of parks, the decisions to visit parks, the types of experiences within the park, and the outcome of those experiences. Likewise, our experiences with and within parks may affect our values, attitudes, beliefs and behaviours towards them. 


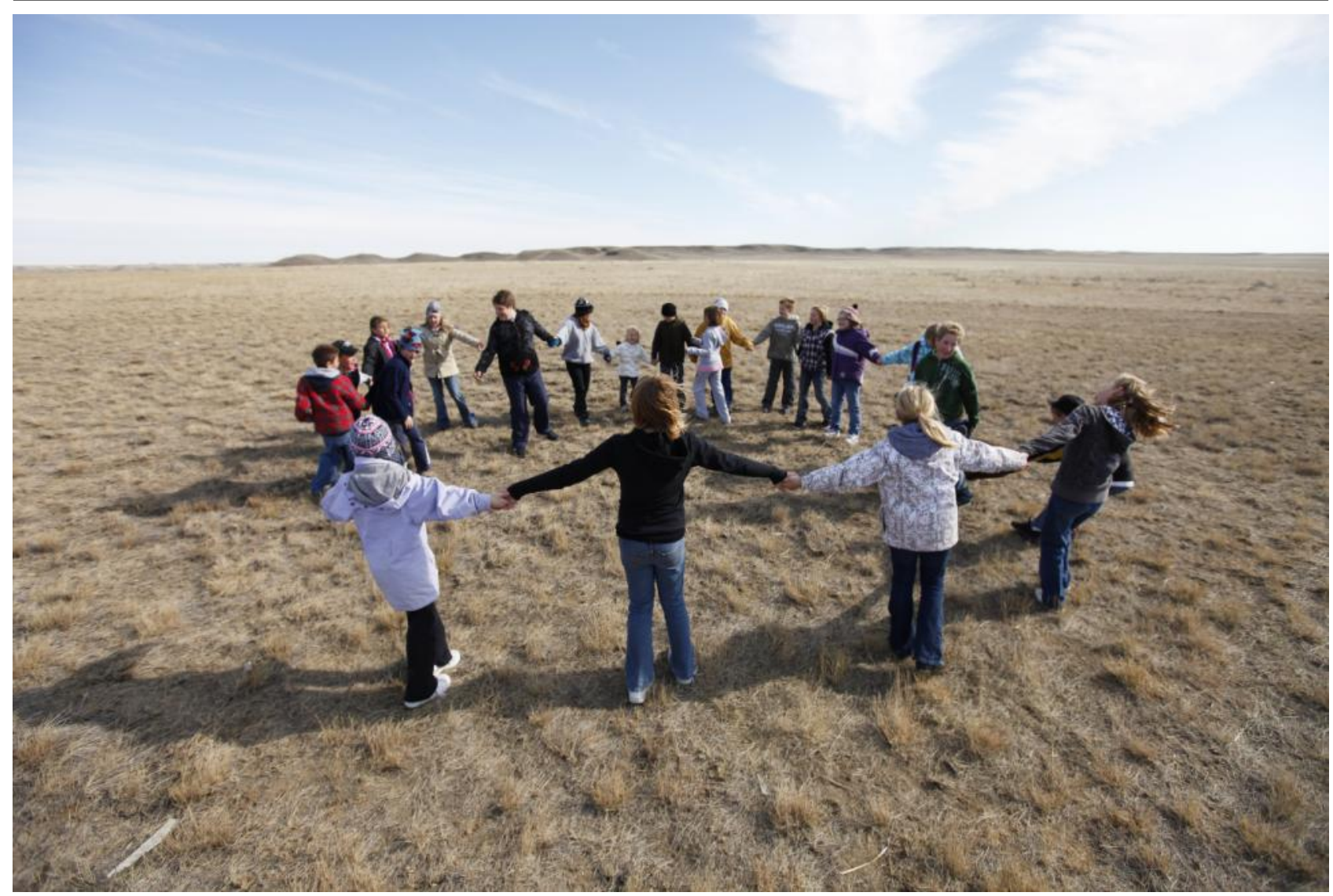

Children playing during the events for the release of the black-footed ferret (Mustela nigripes) at Grasslands National Park, Saskatchewan, Canada @ WWF / Troy Fleece

Environmental values are enduring beliefs that express an end state preferred by individuals or societies (Rokeach, 1973). Values are abstract notions from which attitudes, and ultimately behaviours, might evolve. A worldview can be viewed as a framework for how we understand the world and it is built on these deeply held values. Attitudes rest on this foundation of values and are a collection of beliefs about a specific object or issue such as the environment or parks that includes cognitive (knowledge/fact), affective (feeling/emotion), and behavioural (intended actions) elements.

\section{We bring our worldviews to the park}

Our worldviews are based on deep and enduring value systems that are influenced by the sociocultural context in which we are born and raised. Research suggests that in large part our worldviews (e.g., environmental worldviews) are antecedent to the park visit and may predispose choices regarding the park visit (Lee \& Moscardo, 2005). For example, a number of studies have shown that those holding more eco-centric attitudes (seeing oneself as being subject to nature rather than in control of it) are more likely to participate in nature appreciative activities while those holding more technocentric attitudes (belief that humans have control over nature) are more likely to participate in motorized activities (Dunlap \& Van Liere, 1978; Thapa, 2010).
Significant life events, particularly those that engender a strong level of emotional affinity, can help develop meaning from an experience and influence our worldviews. Thus while most typically our worldviews are set before we visit a park, a park experience may influence worldviews, particularly if it is a significant life event with a strong emotional component.

\section{The linkage between attitude and behaviour}

Attitudes are important to, and may predispose, behaviour (Stern et al., 1995) but there is a significant body of research that demonstrates that many people who hold a particular attitude don't exhibit corresponding behaviours. Numerous researchers note that the linkage between environment and park attitudes and behaviours is weak or modest (Cottrell, 2003; Scott \& Willits, 1994; Tarrant \& Cordell, 1997; Thapa, 1999, 2000), although the link between attitude and planned or intended behaviour is much stronger. In other words, people with positive attitudes towards environment and parks are likely to have good intentions about behaving in a way that supports environment and parks, but they may not actually follow through on these intentions. Attitudes are more likely to lead to positive behaviour if the behaviour is very easy, or if there is confidence that the actions will make a difference (Tarrant \& Cordell, 1997). 


\section{Nature appreciative activities are linked to pro-} environmental behaviours

The relationship between outdoor recreation participation and pro-environmental attitudes has been extensively studied. Early studies found mixed to weak support for the hypothesis that there is a strong relationship between outdoor recreation and environmental attitudes (Dunlap \& Heffernan, 1975; Geisler et al., 1977; Jackson, 1986; Pinhey \& Grimes, 1979; Van Liere \& Noe, 1981). More recent research with improved methods (Teisl \& O'Brien, 2003; Thapa, 2000, 2010; Thapa \& Graefe, 2003) has demonstrated that participation in outdoor recreation results in a stronger relationship between attitudes and behaviours related to nature appreciation behaviours (Tarrant \& Green, 1999; Thapa, 2010). Those who participate in natureappreciative activities have a tendency towards stronger levels of environmental behaviours (e.g., green consumerism) than those who don't (Thapa, 2010) ${ }^{\mathbf{3}}$. Evidence is also mounting that activities involving purposeful nature interactions, such as restoration activities (Ryan et al., 2001) or other nature-based activities (Vorkinn \& Riese, 2001) are associated with increased concern about the health of a place.

\section{Early exposure to nature builds strong connections}

A strong body of research supports the notion that early exposure to nature helps children develop positive environmental attitudes and facilitates a sense of nature connectedness and likely support for conservation in later life (see for example Chawla, 1999). Key factors in childhood experiences include frequency of visits to green space, particularly wild nature; nature experiences that were accompanied and encouraged by trusted adults (e.g., parents); and experiences that are less structured and allow creative free play (Chawla, 1988, 1999; Tanner, 1980, 1998; Wells \& Lekies, 2006). Childhood participation in 'wild nature', unstructured activities has a strong positive association with environmental behaviours in adulthood, in contrast to 'domesticated nature' (e.g., zoo visits, gardening, organized youth groups) experiences that are only weakly associated with pro-environmental behaviours (Wells \& Lekies, 2006).

\section{SENSE OF PLACE \& PARKS}

\section{A strong sense of place may facilitate connections and conservation}

Sense of place is a broad concept that refers to the meanings and attitudes we hold towards a particular locale. When a particular place (like a specific park) plays a key role in an individual's identity - in how the person defines themselves - it is referred to as place identity.
When we are reliant or dependent on a specific place (usually because of a particular activity), it is referred to as place dependence. Together, place identity and place dependence define our place attachment (Ramkissoon et al., 2012; Walker \& Chapman, 2003).

A limited but growing body of research examines the relationships between sense of place and environmental behaviours (Gosling \& Williams, 2010; Kelly \& Bricker, 2000; Stokols \& Shumaker, 1981; Walker \& Chapman, 2003). Interacting with nature increases place attachment and willingness to engage in environmental behaviours (Scannell \& Gifford, 2010). Some studies have found that those with strong place attachments to particular areas are more likely to act as resource stewards, to have more knowledge about the resource, and are less likely to engage in damaging behaviours (Wellman et al., 1982; Williams \& Huffman, 1986). Recent studies within park contexts have supported the relationship between place attachment and conservation behaviours (Halpenny, 2006; Walker \& Chapman, 2003). A study of place attachment to Point Pelee National Park (Canada) found that place attachment predicted place-related pro-environmental intentions. Place identity influences or controls the effects of place dependence in predicting pro-environmental intentions (Halpenny, 2010). There is evidence suggesting that more frequent park visits (Parks Canada, 2011) may correlate to stronger measures of place attachment; however, other research suggests non-park users can also develop a sense of place identity towards parks (Tuan, 1979). Some theorize that more frequent and longer visits may be important to developing a sense of place because they increase familiarity with the place and allow for potential integration of place identity (Tam, 2012; Williams \& Vaske, 2003).

\section{NATURE CONNECTEDNESS}

Nature connectedness refers to the degree to which individuals include nature as part of their identity through a sense of oneness between themselves and the natural world (Dutcher et al., 2007; Schultz, 2002). Exploring individual differences in nature connection can potentially help foster the development of stronger human bonds with the natural world (Nisbet et al., 2011). People with high nature connectedness tend to have frequent, long-term contact with nature and spend the most time outdoors, exhibit ecologically aware attitudes and behaviours ( Nisbet et al., 2009; Parks Canada, 2011; Wellman et al., 1982; Williams \& Huffman, 1986), and be happier (Zelenski \& Nisbet, 2014). Although a strong predictor of nature connectedness is time spent in the outdoors (Chawla, 1999) some research suggests that 
general outdoor settings (as opposed to nature-focused/ natural settings) do not result in an increase in connectedness (Bruni \& Schultz, 2010). Some research suggests that wilderness, as opposed to developed or domesticated nature settings (Wells \& Lekies, 2006), is more strongly related to creating nature connections, and likewise, settings such as hiking trails and beaches are more strongly related than golf courses and other built facilities (Schultz \& Tabanico, 2007).

Cultivate nature connectedness and conservation through emotional nature experiences

Direct contact with nature and experiences with a strong emotional component are related to nature connectedness (Tarrant \& Green, 1999). Although the study of nature connectedness is still in its infancy, there is evidence demonstrating that those who are more connected are more supportive of conservation, and that nature connectedness predicts environmental concern (Dutcher et al., 2007; Mayer \& Frantz, 2004). Recent findings also suggest that at least in the context of urban parks, a sense of nature connectedness is a stronger determinant of park visitation than proximity to parks (Lin et al., 2014.). Ongoing research in Canada has found that the more connected one is to nature, the greater the motivation to visit parks, and the greater health benefits received from park experiences. This research has also found that nature connectedness is positively related to age, frequency of visits, life satisfaction, and perceived state of physical and mental health (Lemieux, 2015).

\section{Intentional interactions with nature are the key to connectedness and action}

Developing nature connectedness is not just a result of any time spent in nature; rather there is evidence that intentionality is critical. Interactions with nature vary from indirect experiences (e.g., looking at nature through a window or watching a movie), to incidental experiences (e.g., being physically present in nature but interacting with nature only as the unintended result of another activity such as cycling to work or downhill skiing in a park), to intentional experiences (e.g., intentionally interacting with nature such as by hiking in a park, viewing wildlife or gardening). Intentional interactions with nature have been identified as pivotal not only in the relationship to nature connectedness, but also critical to the relationship with responsible environmental behaviours (Keniger et al., 2013; Zylstra, 2014).

\section{Nature connectedness is resistant to change but can be enhanced}

Experimental research using nature interventions in non -park settings found that while nature connectedness, like other environmental attitudes, is deeply held it can be enhanced with increased nature contact (Nisbet et al., 2011). Some research has examined the efficacy of specific interventions designed to improve nature connectedness (Chambliss, 2013; Ernst \& Theimer, 2011; Gilbertson, 2013; Tam et al., 2013), but most studies were associated with interventions or experiences in counselling or educational settings. Other research has focused on probing the relationships between nature connectedness and altruism (Chochola, 2009), stewardship activities (Ford, 2008), meaning in life (Creedon, 2012), happiness (Cervinka et al., 2012), mental health (Tauber, 2012), environmental behaviour (Chochola, 2009; Hoot \& Friedman, 2011) and other aspects, but there are relatively few examinations of nature connectedness in parks and protected areas.

\section{Fostering restorative environments may hold promise}

Research findings indicate that natural environments provide for 'soft fascination' experiences - that is experience where sounds, sights and smells attract our attention while still allowing us to function. There is evidence that these kinds of soft fascination experiences are more restorative by nature than hard fascination experiences such as participating in a sporting event or watching TV, which take our full attention and don't allow us to think, reflect and restore. There is potential to study the differences in park activities, and the settings in which they take place, based on the extent to which they provide soft fascination restorative environments (Kaplan, 1995; Olmsted, 1865). Initial research into the restorative functions of spending multiple days in natural environments away from technology have demonstrated not only the capacity to restore executive decisionmaking systems, but also showed promise in increasing creativity and problem solving (Atchley et al., 2012). Those who have stronger feelings of nature connectedness have also reported more positive emotions, vitality, enthusiasm, increased attention, and greater ability to focus on problems (Arnould \& Price, 1993; Ryan et al., 2010). Related research on the notion of mindfulness (Kabat-Zinn, 2003) is focused on whether activities, particularly contemplative activities, will strengthen feelings of nature connectedness (Chambliss, 2013; Howell et al., 2013).

\section{EMOTIONS AND MEANINGFUL NATURE EXPERIENCES}

With the growing emergence of what has been called the 'experience economy', park agencies are moving beyond providing park experiences that are seen as merely satisfying or high quality, focusing instead on facilitating 'meaningful and memorable' experiences. Research 


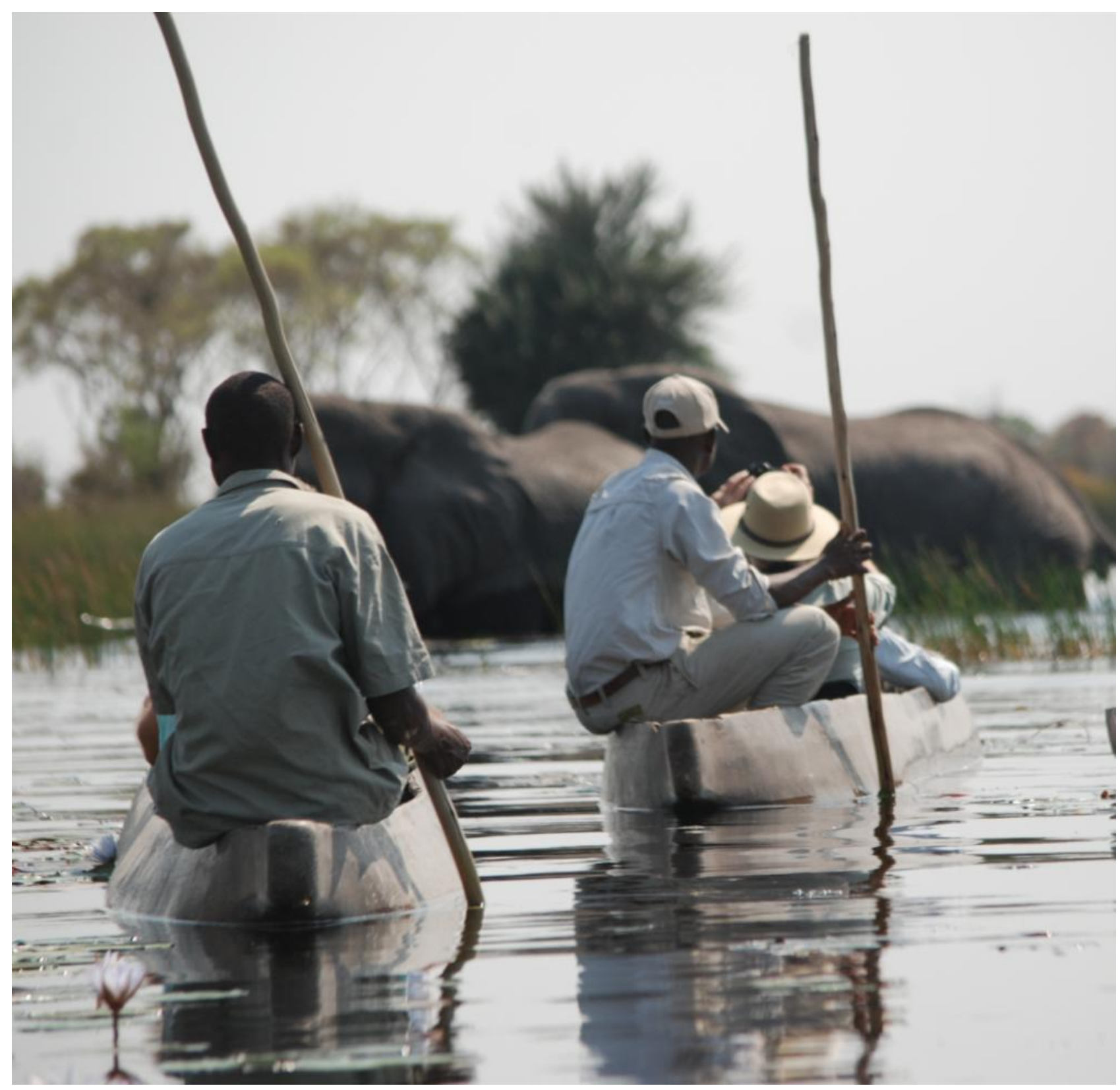

Tourists watching elephants cross a river in the Okavango Delta, Botswana @ Equilibrium Research

addressing the nature of meaningful or memorable experiences provides some insight into what types of experiences may help visitors forge strong connections with nature.

Meaningful nature experiences result in increased personal and conservation benefits

Parks provide an opportunity for the public to have not just meaningful or memorable experiences generally, but meaningful nature experiences (MNE). To be meaningful, these experiences aren't just significant and emotional but they make an impact on an individual's life - what might generally be described as an 'aha' moment. Research suggests that MNEs can be triggered by encounters with wildlife or by spiritual or symbolic experiences (e.g., seeing signs of wildlife or patterns in nature) (McIntosh, 2012). MNEs have been described as leading to increased awareness and sensory perceptions and to intense emotional experiences - often an increased sense of nature connectedness is the result (Zylstra, 2014). Benefits from these experiences include feelings of renewal, restoration, compatibility, connection and satisfaction (Kaplan \& Kaplan, 1989; Morse, 2011). These kinds of experiences with high emotional involvement have also been identified as important to motivating environmentally responsible behaviours (Ballantyne et al., 2011; Chawla, 1999; De Wet, 2007; Kals et al., 1999). This connection between meaningful nature experiences and supportive conservation behaviours results from generating positive views of nature, increasing connectedness, and new ways of seeing and respecting nature. It has also been reported as influencing life paths like career choices (Zylstra, 2014). 


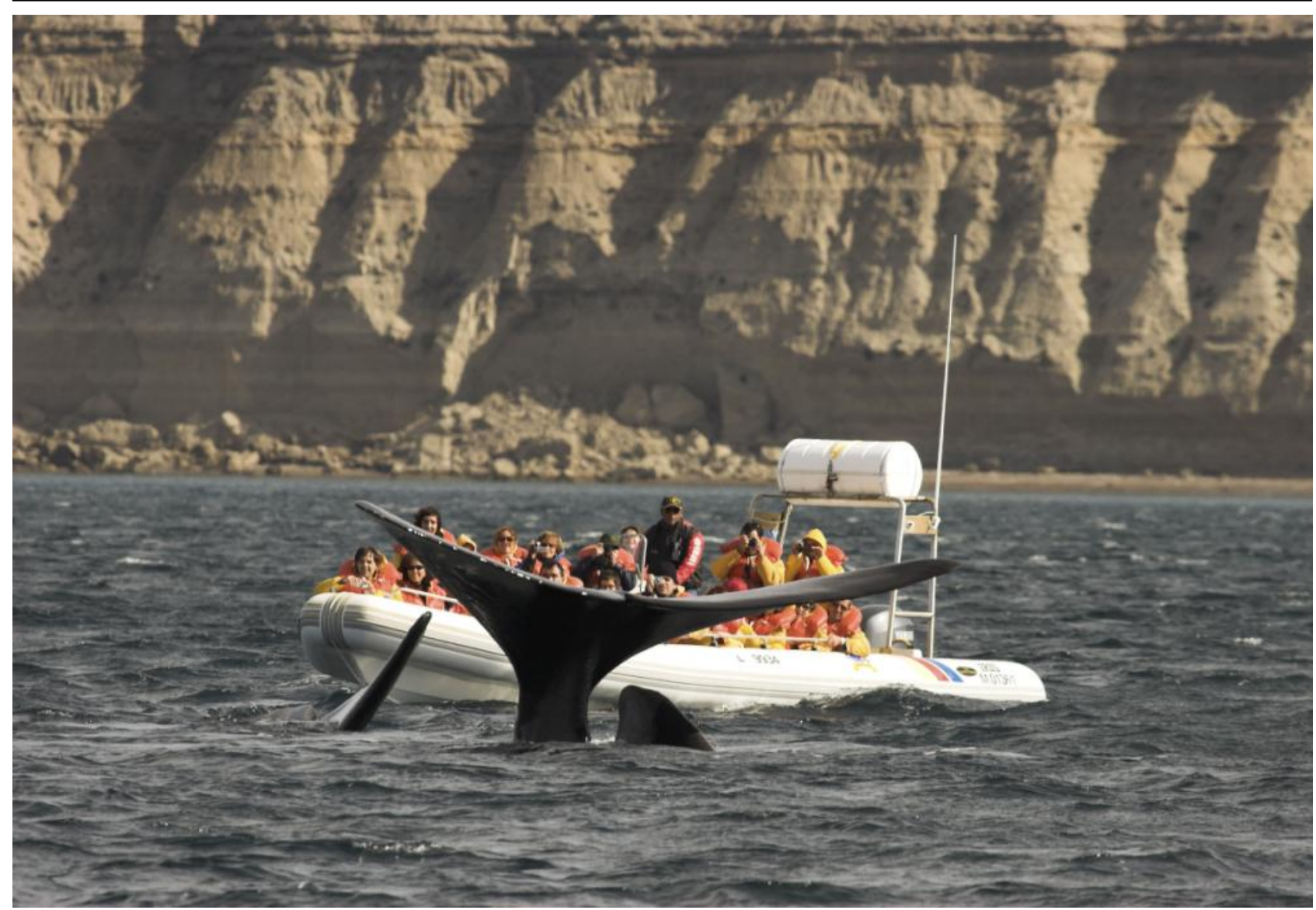

Tourists observe a Southern right whale (Eubalaena australis) and her calf, Patagonia, Argentina @ James Frankham / WWF

\section{Emotions can charge the experience and amplify} nature connectedness

Studies indicate that while attitudes are informed by knowledge they are driven by affect, or emotion. This suggests the importance of park experiences that move beyond an activity opportunity or the transmission of knowledge, to those that nurture an emotional connection to the park environment. At the core of much of this research is an examination of the importance of the emotional or spiritual connections that people have with the place (Arnould \& Price, 1993), the natural environment, or other participants on the trip (Heintzman, 2012; Jefferies \& Lepp, 2012; Stringer \& McAvoy, 1992). However, in spite of the emphasis among park agencies on encouraging meaningful and memorable experiences that foster nature connectedness, there is still little information available to guide management in successfully connecting visitors with nature (Farber \& Hall, 2007).

Emotions are critical in contributing to impactful or memorable experiences and in developing empathy towards the natural world, and thus are central to understanding nature connectedness and related outcomes such as support for parks (Kals et al., 1999; Nisbet et al., 2009; Vining, 1987). A significant body of literature points to the emotional connections between humans and nature (Kals et al., 1999; Mayer \& Frantz, 2004). Empathy towards nature and sense of place is correlated with responsible environmental behaviours (Walker \& Chapman, 2003). Development of empathy is facilitated by positive experiences, particularly those that occur over a length of time, and sharing these experiences with others (Kals et al., 1999; McIntosh, 2012). So while there is a strong body of evidence that attributes significant benefits to visitors from even short visits to parks, longer visits that create opportunities for emotionally impactful experiences are more associated with nature connectedness and ultimately more likely to lead to environmentally responsible behaviours. And while frequency of time in nature, and time in nature between the ages of 7-12, have been identified as the most significant predictors of attitudes towards nature (Kals et al., 1999; Tanner, 1998), there is some suggestion that a meaningful nature experience itself can result in high nature connectedness (Zylstra, 2014).

\section{Knowledge may not be king}

Although park interpretive and educational programmes that focus on enhancing knowledge can be a valuable part of the park experience, information can, but does not always, affect attitudes or behaviours (Ham, 2007; Tubb, 2003). Some research has found that highly engaging, thought provoking and emotionally connected 
activities may both reinforce existing attitudes and have the potential to help develop new attitudes or promote changes in park behaviours (Cacioppo \& Petty, 1989; Werner et al., 1998). Preliminary research suggests that interpretive programmes can increase feelings of nature connectedness, particularly if they complement knowledge-based learning with emotional connections to nature or to place. However, research on the influence of interpretive programming on behaviours in natural areas is limited and lacks robustness (Munro et al., 2008; Weiler et al., 2013).

\section{GAPS IN KNOWLEDGE AND AREAS FOR FUTURE RESEARCH}

Although there is increasing interest in the issues of connecting people with nature and a growing body of research (see for example Maller et al., 2008), many significant gaps remain.

Barriers to visitation. Although there is much speculation, there is little empirical evidence investigating the barriers to park visitation - particularly in non-urban park settings. More research should be conducted to investigate barriers and the success of approaches used to overcome barriers. For example, is there a lack of interest in visiting parks among some segments of the population, and if so, why and for whom is lack of interest (as opposed to opportunity constraints) the driving reason behind the decision to not visit a park? Are increasing urbanization, aging populations and other social change phenomena associated with a lack of interest, or opportunity in park visits? Do recreational experiences in nature, particularly urban experiences, generate or maintain connectedness to nature; are urban park/nature experiences truly gateway experiences leading to other park visits?

Activities and infrastructure. Some protected areas agencies are responding to declines in visitation or concerns about connectedness by offering new activities and infrastructures that often challenge the norms of acceptable park based activities (e.g. Glacier Skywalk in Jasper National Park, AB, Canada). These activities are justified by claims of reaching underserved or nontraditional park audiences, disadvantaged audiences or providing opportunities to truly connect with nature but there is limited, if any, evidence to examine these claims. What audience is attracted (vs deterred) by new, built infrastructure based opportunities in parks; do these result in increases (and long-lasting increases) in visitation; do these activities provide opportunities for people to have meaningful nature experiences; what activities and settings facilitate connectedness to nature in parks; and what park experiences are associated with the 'intentional interaction' with nature so important to nature connectedness?

Attitudes towards parks and nature. Continuing to build on research on the nature and role of attitudes about parks and conservation there is a need for empirical research (beyond simple polls) on a number of related topics including: the attitudes that visitors and nonvisitors hold towards parks and how and when these attitudes are developed; the role park visits have in shaping or influencing environmental attitudes and worldviews and/or conversely the role existing environmental attitude and worldviews have in influencing park visits; how outdoor activities influence the relationship between attitude and behaviour within a park-type setting (with park-focused activities); and what park-specific appreciative attitudes and behavioural intentions do non-park visitors have and why.

Sense of place. More research is needed in our growing understanding of the relationship between parks and place attachment. For example studies that: explore the role of place-specific emotions and feelings (using indepth/longitudinal measurements) and place identity in fostering pro-environmental behaviour; or investigate the relationship of place attachment to proenvironmental behaviour in park settings; and examining how place attachment can be strengthened?

Nature connectedness. In the new field of nature connectedness many questions remain including: how and why people have such varying levels of nature connectedness; whether nature connectedness relates to one's motivation to visit parks; and how does nature connectedness relate to the benefits received from park experiences? Additionally, empirical evaluations are needed of programmes or experiences within or about parks designed to improve nature connectedness.

Culture of conservation. Finally, more research should be conducted to determine how to facilitate a culture of conservation and action among park visitors and the kinds of environmentally-responsible behaviours and park-supportive behaviours that can be facilitated.

\section{CONCLUSIONS - THE OPPORTUNITY TO LEARN THROUGH PRACTICE}

Park agencies, non-governmental organizations and others are engaged in a wide array of initiatives to try to better connect people to nature with, and within, parks. In Canada, outreach campaigns to new Canadians, the establishment of a new national urban park in Toronto, 
learn-to-camp programmes and park volunteer programmes are just some of the new strategies being employed and organizations around the world are engaged in similar creative initiatives. An excellent opportunity exists to advance the state of knowledge and ultimately, practice. There is an opportunity to learn from the management actions undertaken by protected area agencies and others if they are structured within an adaptive management framework to support evidencebased research.

\section{ENDNOTES}

${ }^{1}$ Some have critiqued this notion of a 'disconnect' as the privilege of more developed nations but initiatives to combat this issue are increasingly widespread as evidenced by 2007 initiatives by South African Parks (http://www.sanparks.org/about/news/?id=622) and widespread initiatives in China (http:// www.theguardian.com/environment/2012/jan/11/ children-china-urban-jungle-nature).

${ }^{2}$ For example, Parks Canada has formally set an objective of increasing visitation to national parks by 10 per cent between 2010 and 2015 (Parks Canada, 2010).

${ }^{3}$ Notably, this body of research did not take place in 'national park' type locations, suggesting a need to replicate these types of studies in park settings.

\section{ACKNOWLEDGEMENTS}

This research was the result of a partnership between the University of Northern British Columbia and the Canadian Parks and Wilderness Society and was funded, in part, by support from the Schad Foundation. The authors thank E. Halpenny, C. Lemieux, P. Mullins, L. Nisbet, E. Riccius and J. Shultis for review of an earlier version of this article.

\section{ABOUT THE AUTHORS}

Dr. Pamela Wright is a faculty member in the Ecosystem Science and Management programme at the University of Northern British Columbia (UNBC). She conducts research and teaches on topics related to conservation, parks and protected areas, ecological integrity monitoring and the well-being benefits of parks and outdoor recreation. Along with other colleagues on the Panel on the Ecological Integrity of Canada's National Parks, she was awarded the J.B. Harkin award for conservation in 2010.

Carling Matthews grew up in northern British Columbia and completed her undergraduate degree in Outdoor Recreation and Nature-Based Tourism Management at UNBC. Currently a master's student at UNBC, her thesis explores nature connected- ness and well-being from a rural perspective. She lives and works in Jasper National Park, AB, Canada.

\section{REFERENCES}

Amend, T., Brooks, T., Choudhury, B. C., Coad, L., Dudley, N., Hockings, M., Kormos, C., Lopoukhine, N., Lotter, W., MacKinnon, K., Newing, H., Redford, K.H., Stolton, S. and Verschuuren, B. (2014). Publishing for the protected area community: a vision for PARKS from its editorial board. Parks. 20(2),7-12. DOI: 10.2305/IUCN.CH.2014.PARKS-202.TA.en

Arnould, E. J. and Price, L. L. (1993). River magic: extraordinary experience and the extended service encounter. Journal of Consumer Research, 20(1), 24. http://dx.doi.org/10.1086/209331

Atchley, R. A., Strayer, D. L. and Atchley, P. (2012). Creativity in the wild: Improving creative reasoning through immersion in natural settings. PloS One, 7(12), e51474.DOI: 10.1371/journal.pone.0051474

Ballantyne, R., Packer, J. and Sutherland, L. A. (2011). Visitors' memories of wildlife tourism: Implications for the design of powerful interpretive experiences. Tourism Management, 32(4), 770-779. DOI: 10.1016/ j.tourman.2010.06.012

Balmford, A., Beresford, J., Green, J., Naidoo, R., Walpole, M. and Manica, A. (2009). A global perspective on trends in nature-based tourism. PLoS Biology, 7(6), e1000144. DOI: 10.1371/journal.pbio.1000144

Bruni, C. M. and Schultz, P. (2010). Implicit beliefs about self and nature: Evidence from an IAT game. Journal of Environmental Psychology, 30(1), 95-102.DOI: 10.1016/ j.jenvp.2009.10.004

Cacioppo, J. T. and Petty, R. E. (1989). Effects of message repetition on argument processing, recall, and persuasion. Basic and Applied Social Psychology, 10(1), 3-12. DOI: 10.1207/s15324834basp1001_2

Canadian Parks and Wilderness Society (CPAWS). (2013). State of Canada's Parks Report 2013: One step forward/ two steps back. Ottawa, ON: CPAWS.

Canadian Parks Council/Parks Canada. (2014). Connecting Canadians with Nature - An Investment in the Well-Being of our Citizens. Ottawa, ON: Parks Canada. 
Cervinka, R., Röderer, K. and Hefler, E. (2012). Are nature lovers happy? On various indicators of well-being and connectedness with nature. Journal of Health Psychology, 17(3), 379-388. DOI:10.1177/1359105311416873

Chambliss, K. M. (2013). Beholding Nature: Contemplation and Connectedness (Ph.D.). Prescott College, United States - Arizona.

Chawla, L. (1988). Children's concern for the natural environment. Children's Environments Quarterly, 13-20.

Chawla, L. (1999). Life paths into effective environmental action. The Journal of Environmental Education, 31(1), 1526. DOI: $10.1080 / 00958969909598628$

Chochola, L. J. (2009). Exploring altruism as a possible moderator between connectedness to nature and proenvironmental behavior (Ph.D.). Alliant International University, Los Angeles, United States - California.

Cottrell, S. P. (2003). Influence of Sociodemographics and Environmental Attitudes on General Responsible Environmental Behavior among Recreational Boaters. Environment and Behavior, 35(3), 347-375. DOI: $10.1177 / 0013916503035003003$

Crawford, D. W., Jackson, E. L. and Godbey, G. (1991). A hierarchical model of leisure constraints. Leisure Sciences, 13(4), 309-320. DOI:10.1080/01490409109513147

Creedon, M. A. (2012). Connectedness to nature and its relationship to meaning in life (Psy.D.). Massachusetts School of Professional Psychology, United States Massachusetts.

De Wet, B. (2007). Influence of wilderness experience on the adoption of environmentally responsible behaviour (MSC thesis). Stellenbosch University, Stellenbosch.

Dunlap, R. E. and Heffernan, R. B. (1975). Outdoor Recreation and Environmental Concern: An Empirical Examination. Rural Sociology.

Dunlap, R. E. and Van Liere, K. D. (1978). The 'New Environmental Paradigm': A proposed measuring instrument and preliminary results. The Journal of Environmental Education, 9(4), 10-19. DOI: 10.1111/00224537.00176

Dutcher, D. D., Finley, J. C., Luloff, A. E. and Johnson, J. B. (2007). Connectivity with nature as a measure of environmental values. Environment and Behavior, 39(4), 474-493. http://doi.org/10.1177/0013916506298794

Environics Institute. (2009). 2009 National Survey of Canadians. Retrieved from http://epe.lacbac.gc.ca/100/200/301/pwgsc-tpsgc/por-ef/ parks_canada/2009/055-08-e/report.pdf

Ernst, J. and Theimer, S. (2011). Evaluating the effects of environmental education programming on connectedness to nature. Environmental Education Research, 17(5), 577598.

Farber, M. E. and Hall, T. E. (2007). Emotion and environment: visitors' extraordinary experiences along the Dalton Highway in Alaska. Journal of Leisure Research, 39(2), 248 -270 .

Ford, H. L. (2008). Stewardship volunteers: Well-being and connectedness to nature through conservation work (M.A.). Royal Roads University, Canada.

Geisler, C. C., Martinson, O. B. and Wilkening, E. A. (1977). Outdoor recreation and environmental concern: a restudy. Rural Sociology, 42(2), 241-249.

Gilbertson, E. (2013). When nature speaks: Evoking connectedness with nature in children through role-play in outdoor programming (Masters Thesis). Royal Roads University, Canada.
Gosling, E. and Williams, K. J. H. (2010). Connectedness to nature, place attachment and conservation behaviour: Testing connectedness theory among farmers. Journal of Environmental Psychology, 30(3), 298-304. DOI: 10.1016/ j.jenvp.2010.01.005

Halpenny, E. A. (2006). Environmental Behaviour, Place Attachment and Park Visitation: A case study of visitors to Point Pelee National Park. (Ph.D.) University of Waterloo, Ontario, Canada.

Halpenny, E. A. (2010). Pro-environmental behaviours and park visitors: The effect of place attachment. Journal of Environmental Psychology, 30(4), 409-421. DOI: 10.1016/ j.jenvp.2010.04.006

Ham, S. (2007). Can interpretation really make a difference? Answers to four questions from cognitive and behavioral psychology. In Proceedings, Interpreting World Heritage Conference, March (pp. 25-29).

Hart Research Associates, \& North Star Opinion Research. (2012). Strong Bipartisan Support for National Parks. Findings from a national survey conducted on behalf of The National Parks Conservation Association and National Park Hospitality Association. Retrieved from http:// w w w. n p c a org/ass e t s/pdf/ Suvey_Findings_Memo_Final.pdf

Heintzman, P. (2012). Spiritual Outcomes of Wilderness Experience: A synthesis of recent social science research. PARKScience, 28(3).

Hoot, R. E. and Friedman, H. (2011). Connectedness and Environmental Behavior: Sense of Interconnectedness and Pro-Environmental Behavior. International Journal of Transpersonal Studies, 30(1/2), 89-100.

Howell, A. J., Passmore, H.-A. and Buro, K. (2013). Meaning in Nature: Meaning in Life as a Mediator of the Relationship between Nature Connectedness and Well-Being. Journal of Happiness Studies, 14(6), 1681-1696.

Hubbard, J. and Mannell, R. C. (2001). Testing Competing Models of the Leisure Constraint Negotiation Process in a Corporate Employee Recreation Setting. Leisure Sciences, 23(3), 145-163.

IPCC. (2014). Climate Change 2014: Impacts, Adaptation and Vulnerability. IPCC Secretariat.

Ipsos Reid. (2011). Nine in Ten (87\%) Canadians Say That When Connected to Nature They Feel Happier.

Jackson, E. L. (1986). Outdoor recreation participation and attitudes to the environment. Leisure Studies, 5(1), 1-23. DOI: 10.1080/02614368600390011

Jefferies, K. and Lepp, A. (2012). An Investigation of Extraordinary Experiences. Journal of Park \& Recreation Administration, 30(3).

Kabat-Zinn, J. (2003). Mindfulness-based interventions in context: past, present, and future. Clinical Psychology: Science and Practice, 10(2), 144-156. DOI: 10.1093/ clipsy.bpg016

Kals, E., Schumacher, D. and Montada, L. (1999). Emotional affinity toward nature as a motivational basis to protect nature. Environment and Behavior, 31(2), 178-202. DOI: $10.1177 / 00139169921972056$

Kaplan, S. (1995). The restorative benefits of nature: Toward an integrative framework. Journal of Environmental Psychology, 15(3), 169-182. DOI:10.1016/0272-4944(95) 90001-2

Kaplan, R. and Kaplan, S. (1989). The experience of nature: A psychological perspective. CUP Archive.

Kelly S. and Bricker, D. L. K. (2000). Level of Specialization and Place Attachment: An Exploratory Study of Whitewater 
Recreationists. Leisure Sciences, 22(4), 233-257. DOI:10.1080/01490409950202285

Keniger, L., Gaston, K. J., Irvine, K. N. and Fuller, R. (2013). What are the benefits of interacting with nature? International Journal of Environmental Research and Public Health, 10.

Lee, W. H. and Moscardo, G. (2005). Understanding the impact of ecotourism resort experiences on tourists' environmental attitudes and behavioural intentions. Journal of Sustainable Tourism, 13(6), 546-565. DOI: 10.1080/09669580508668581

Lemieux, C. J., Doherty, S.T., Eagles, P.F.J., Gould, J., Hvenegaard, G.T., Nisbet, E. and Groulx, M.W. (2015). Healthy Outside-Healthy Inside: the human health and well-being benefits of Alberta's protected Areas - towards $a$ benefits-based management agenda. Canadian Council on Ecological Areas (CCEA) Occasional Paper No. 20. CCEA Secretariat, Ottawa, Ontario, Canada.

Lin, B., Fuller, R., Bush, R., Gaston, K. J. and Shanahan, D. (2014). Opportunity or Orientation? Who Uses Urban Parks and Why. PLoS One, 9(1), 1-7. DOI: 10.1371/ journal.pone.0087422

Lopoukhine, N., Wheeler, K., Keenleyside, K., Charles, C., Koss, R. and Nicoll, R. (2014.). Empowering the next generation to connect with nature: A global movement. Parks. 20 (2),49-60. DOI: 10.2305/IUCN.CH.2014.PARKS-20-2.NL.en

Louv, R. (2008). Last child in the woods: Saving our children from nature-deficit disorder. Algonquin Books.

Maller, C., Townsend, M., Henderson-Watson, C., Pryor, A., Prosser, L., Moore, M. and Leger, L. (2008). Healthy parks, healthy people: The health benefits of contact with nature in a park context. Deakin University and Parks Victoria.

Mayer, F. S. and Frantz, C. M. (2004). The connectedness to nature scale: A measure of individuals' feeling in community with nature. Journal of Environmental Psychology, 24(4), 503-515. http://dx.doi.org/10.1016/ j.jenvp.2004.10.001

McIntosh, D. (2012). Wildlife viewing in the mountain national parks of Canada: an experiential view (MA NRES). University of Northern British Columbia, Prince George, BC.

Morse, M. (2011). River experience: A phenomenological description of meaningful experiences on a wilderness river journey. (Ph.D. Dissertation). University of Tasmania, Hobart.

Munro, J. K., Morrison-Saunders, A. and Hughes, M. (2008). Environmental interpretation evaluation in natural areas. Journal of Ecotourism, 7(1), 1-14. DOI:10.2167/joe137.0

Nisbet, E. K., Zelenski, J. M. and Murphy, S. A. (2009). The nature relatedness scale: Linking individuals' connection with nature to environmental concern and behavior. Environment and Behavior, 41(5), 715-740. DOI:10.1177/0013916508318748

Nisbet, E., Zelenski, J. and Murphy, S. (2011). Happiness is in our nature: Exploring nature relatedness as a contributor to subjective well-being. Journal of Happiness Studies, 12 (2), 303-322.

OAGBC. (2010). Conservation of Ecological Integrity in B.C. Parks and Protected Areas (Report 3). Retrieved from http://www.bcauditor.com/pubs/2010/report3/ conservation-ecological-integrity-bc-parks-protected

Office of the Auditor General of Canada. (2013). Report of the Commissioner of the Environment and Sustainable Development. Retrieved from http://www.oag-bvg.gc.ca/ internet/English/parl_cesd_201311_07_e_38677.html
Olmsted, F. L. (1865). The value and care of parks. Reprinted in R. Nash (Ed.), The American environment: Readings in the history of conservation.

Parks Canada. (2011). The VALUE of Visiting National Parks. Social Science Branch (ERVE).

Parks Canada Agency. (2011). State of Canada's Natural and Historic Places 2011. Ottawa, ON: Government of Canada.

Parks Canada Agency. (2013). Parks Canada Attendance 200809 to 2012-13.

Pergams, O. R. W. and Zaradic, P. A. (2008). Evidence for a fundamental and pervasive shift away from nature-based recreation. Proceedings of the National Academy of Sciences, 105(7), 2295-2300. DOI: 10.1073/ pnas.0709893105

Pinhey, T. K. and Grimes, M. D. (1979). Outdoor recreation and environmental concern: A reexamination of the Dunlap-Heffernan thesis. Leisure Sciences, 2(1), 1-11.

Ramkissoon, H., Weiler, B. and Smith, L. D. G. (2012). Place attachment and pro-environmental behaviour in national parks: The development of a conceptual framework. Journal of Sustainable Tourism, 20(2), 257-276. http:// dx.doi.org/10.1080/09669582.2011.602194

Rokeach, M. (1973). The nature of human values. Free press.

Ryan, R. L., Kaplan, R. and Grese, R. E. (2001). Predicting volunteer commitment in environmental stewardship programmes. Journal of Environmental Planning and Management, 44(5), 629-648.

Ryan, R. M., Weinstein, N., Bernstein, J., Brown, K. W., Mistretta, L. and Gagné, M. (2010). Vitalizing effects of being outdoors and in nature. Journal of Environmental Psychology, 30(2), 159-168. DOI:10.1016/ j.jenvp.2009.10.009

Scannell, L. and Gifford, R. (2010). The relations between natural and civic place attachment and pro-environmental behavior. Journal of Environmental Psychology, 30(3), 289 -297.DOI: 10.1016/j.jenvp.2010.01.010

Schultz, P. W. (2002). Inclusion with Nature: The Psychology of Human-Nature Relations. In P. Schmuck and W. P. Schultz (Eds.), Psychology of Sustainable Development (pp. 61-78). Springer, USA.

Schultz, P. and Tabanico, J. (2007). Self, Identity, and the Natural Environment: Exploring Implicit Connections With Nature1. Journal of Applied Social Psychology, 37(6), 1219 -1247. DOI: 10.1111/j.1559-1816.2007.00210.x

Scott, D. and Mowen, A. J. (2010). Alleviating park visitation constraints through agency facilitation strategies. Journal of Leisure Research, 42(4), 535-550.

Scott, D. and Willits, F. K. (1994). Environmental Attitudes and Behavior: A Pennsylvania Survey. Environment and Behavior, 26(2), 239-260. DOI: 10.1177/001391659402600206

Shultis, J. and More, T. (2011). American and Canadian National Park Agency Responses to Declining Visitation. Journal of Leisure Research, 43(1), 110-132.

Stern, P. C., Dietz, T. and Guagnano, G. A. (1995). The New Ecological Paradigm in Social-Psychological Context. Environment and Behavior, 27(6), 723-743. doi: 10.1177/0013916595276001

Stokols, D. and Shumaker, S. A. (1981). People in places: A transactional view of settings. In J. Harvey (Ed.), Cognition, social behavior, and the environment (pp. 441-488). Hillsdale, NJ: Erlbaum.

Stringer, L. A. and McAvoy, L. H. (1992). The Need for Something Different: Spirituality and Wilderness 
Adventure. Journal of Experiential Education, 15(1), 1320.

Tam, J. (2012). Fostering Connections between Youth and the Environment in British Columbia. Institute for Resources, Environment and Sustainability, UBC.

Tam, K.-P., Lee, S.-L. and Chao, M. M. (2013). Saving Mr. Nature: Anthropomorphism enhances connectedness to and protectiveness toward nature. Journal of Experimental Social Psychology, 49(3), 514-521. DOI: 10.1016/j.jesp.2013.02.001

Tanner, T. (1980). Significant life experiences: A new research area in environmental education. The Journal of Environmental Education, 11(4), 20-24.

Tanner, T. (1998). Choosing the right subjects in significant life experiences research. Environmental Education Research, 4(4), 399-417. DOI:10.1080/1350462980040404

Tarrant, M. A. and Cordell, H. K. (1997). The effect of respondent characteristics on general environmental attitude-behavior correspondence. Environment and Behavior, 29(5), 618-637. DOI: $10.1177 / 0013916597295002$

Tarrant, M. A. and Green, G. T. (1999). Outdoor Recreation and the Predictive Validity of Environmental Attitudes. Leisure Sciences, 21(1), 17-30.

Tauber, P. G. (2012). An exploration of the relationships among connectedness to nature, quality of life, and mental health (M.S.). Utah State University, United States - Utah.

Teisl, M. F. and O'Brien, K. (2003). Who Cares and Who Acts? Outdoor Recreationists Exhibit Different Levels of Environmental Concern and Behavior. Environment and Behavior, 35(4), 506-522. DOI: $10.1177 / 0013916503035004004$

Thapa, B. (1999). Environmentalism: The Relation of Environmental Attitudes and Environmentally Responsible Behaviors Among Undergraduate Students. Bulletin of Science, Technology \& Society, 19(5), 426-438. DOI: 10.1177/027046769901900512

Thapa, B. (2000). The association of outdoor recreation activities and environmental attitudes and behaviors among forest recreationists (Ph.D). The Pennsylvania State University, University Park, PA.

Thapa, B. (2010). The Mediation Effect of Outdoor Recreation Participation on Environmental Attitude-Behavior Correspondence. The Journal of Environmental Education, 41(3), 133-150. DOI:10.1080/00958960903439989

Thapa, B. and Graefe, A. R. (2003). Forest Recreationists and Environmentalism. Journal of Park \& Recreation Administration, 21(1), 75-103.

Trzyna, T. (2007). Global Urbanization and Protected Areas. Sacramento, California: California Institute of Public Affairs.

Trzyna, T. (2014). Urban Protected Areas: Profiles and best practice guidelines. Best Practice Protected Area Guidelines Series No. 22, Gland, Switzerland, IUCN.

Tuan, Y.-F. (1979). Space and place: humanistic perspective. Springer.

Tubb, K. N. (2003). An evaluation of the effectiveness of interpretation within Dartmoor National Park in reaching the goals of sustainable tourism development. Journal of Sustainable Tourism, 11(6), 476-498. DOI: $10.1080 / 09669580308667217$

Van Liere, K. D. and Noe, F. P. (1981). Outdoor recreation and environmental attitudes: further examination of the
Dunlap-Heffernan thesis. Rural Sociology, 46(3), 505-513. DOI: $10.1177 / 105382590903200107$

Vining, J. (1987). Environmental decisions: The interaction of emotions, information, and decision context. Journal of Environmental Psychology, 7(1), 13-30. DOI: 10.1177/0013916592241001

Vorkinn, M. and Riese, H. (2001). Environmental Concern in a Local Context: The Significance of Place Attachment. Environment and Behavior, 33(2), 249-263. DOI: 10.1177/00139160121972972

Walker, G. J. and Chapman, R. (2003). Thinking Like a Park: The Effects of Sense of Place, Perspective-Taking, and Empathy on Pro-Environmental Intentions. Journal of Park \& Recreation Administration, 21(4).

Weiler, B., Moore, S. A. and Moyle, D. B. (2013). Building and sustaining support for national parks in the 21st century: Why and how to save the national park experience from extinction. Journal of Park and Recreation Administration, 31(2), 110-126.

Wellman, J. D., Roggenbuck, J. W. and Smith, A. C. (1982). Recreation specialization and norms of depreciative behaviour among canoeists. Journal of Leisure Research, 14(4), 323-340.

Wells, N. M. and Lekies, K. S. (2006). Nature and the Life Course: Pathways from Childhood Nature Experiences to Adult Environmentalism. Children, Youth and Environments, 16(1), 1-24.

Werner, C. M., Rhodes, M. U. and Partain, K. K. (1998). Designing Effective Instructional Signs with Schema Theory Case Studies of Polystyrene Recycling. Environment and Behavior, 30(5), 709735.doi: 10.1177/001391659803000506

White, D. D. (2008). A structural model of leisure constraints negotiation in outdoor recreation. Leisure Sciences, 30(4), 342-359. DOI: 10.1080/01490400802165131

Williams, D. R. and Huffman, M. G. (1986). Recreation specialization as a factor in backcountry trail choice. General Technical Report, Intermountain Research Station, USDA Forest Service, (INT-212), 339-344.

Williams, D. R. and Vaske, J. J. (2003). The measurement of place attachment: Validity and generalizability of a psychometric approach. Forest Science, 49(6), 830-840.

Zanon, D., Doucouliagos, C., Hall, J. and Lockstone-Binney, L. (2013). Constraints to Park Visitation: A Meta-Analysis of North American Studies. Leisure Sciences, 35(5), 475-493. DOI: 10.1080/01490400.2013.831294

Zelenski, J. M. and Nisbet, E. K. (2014). Happiness and feeling connected: The distinct role of nature relatedness. Environment and Behavior, 46(1), 3-23. DOI:10.1177/0013916512451901

Zylstra, M. (2014). Exploring meaningful nature experience connectedness with nature and the revitalization of transformative education for sustainability (Dissertation). Stellenbosch University, South Africa. 


\section{RESUMEN}

Más allá de los innumerables valores ecológicos, económicos y culturales que ofrecen, los parques proporcionan un elemento fundamental para el mundo natural, y en una sociedad cada vez más urbanizada y ajetreada son espacios importantes para la consolidación del capital social y la construcción de una cultura de conservación entre los ciudadanos. Muchos organismos encargados de la gestión de parques están enfocados en atraer más visitantes a los parques y ofrecer una gama más amplia de oportunidades para sus visitantes en procura de apoyo para los parques y las áreas protegidas en el futuro. Sin embargo, hay pocas pruebas empíricas para orientar a los administradores de parques y los responsables políticos sobre los tipos de actividades/experiencias más indicadas para conectar a las personas con la naturaleza en procura de aumentar el apoyo a la conservación. Examinamos la literatura disponible para identificar lo que se sabe acerca de la vinculación entre las experiencias de los visitantes en los parques y el apoyo público a favor de la conservación, identificar las lagunas en materia de investigación, y esbozar una agenda de investigación con el fin de aportar pruebas más consistentes para orientar la gestión de parques. Se establecieron cinco temas principales y necesidades de investigación específicas: limitaciones para realizar visitas a los parques, actitudes hacia los parques, sentido de apego al lugar, conexión con la naturaleza, y experiencias estimulantes relacionadas con la naturaleza.

\section{RÉSUMÉ}

Au-delà des valeurs écologiques, économiques et culturelles multiples qu'ils fournissent, les parcs sont un reflet direct du monde naturel et, dans une société de plus en plus urbanisée et trépidante, ils constituent des espaces essentiels pour créer du lien social et pour bâtir une culture de conservation parmi les citoyens. De nombreux organismes responsables de parcs redoublent d'efforts pour attirer davantage de visiteurs et leur offrir un plus grand éventail de possibilités, cherchant à rallier davantage de soutien pour les parcs et les aires protégées dans le futur. Cependant, il y a peu de données empiriques pour aider les gestionnaires des parcs à déterminer quels types d'activités et d'expériences pourront mieux rapprocher les gens de la nature de manière à accroître leur soutien à la cause de la conservation. Nous avons effectué une recherche documentaire afin de déterminer ce que l'on sait du lien entre l'expérience des visiteurs dans les parcs et le soutien public à la conservation; d'identifier les lacunes dans les travaux de recherche réalisés à ce sujet; et d'élaborer un programme de recherche afin de constituer un dossier solide pour orienter les mesures de gestion du parc. Cinq grands thèmes et des pistes de recherche ont été identifiés: les entraves aux visites touristiques, les attitudes envers les parcs, le sentiment d'appartenance, le sentiment de connexion à la nature, et les expériences enrichissantes au sein de la nature. 